\title{
Impact of E-Learning Media on Students' Critical Thinking Skills at Physics Education Study Program, Almuslim University
}

\author{
Marnita ${ }^{1}$, Rahma ${ }^{2}$, Fatimah ${ }^{3}$ \\ Universitas Almuslim, Indonesia ${ }^{1,2.3}$ \\ mar.marnita@yahoo.com¹, rahma@umuslim.ac.id ${ }^{2}$, fatimah@umuslim.ac.id ${ }^{3}$ \\ Received: August $28^{\text {th }}, 2020$. Revised: November $3^{\text {rd }}, 2020$. Accepted: November $5^{\text {th }}, 2020$
}

Keywords :

E-learning; Critical Thinking

Skills; Media

\begin{abstract}
Starting from the emergence of student boredom in taking part in the course of recovery, resulting in decreased thinking skills of students who focus more on memorizing concepts instead of understanding concepts. The researcher combines the learning model assisted by e-learning which is currently of interest. The learning model assisted by elearning media combines principles in the learning process and technology. This study aims to determine the impact of learning with e-learning media on the improvement of critical thinking skills of students in semester III of the physics education study program. Data collection for this research was carried out in September-October 2019, this research is also the impact of the accompaniment of the PDS Grant in won by FKIP Umuslim in the 2019 budget year. Data analysis in this study used a parametric statistical test, namely the one-tail t-test. The results showed that the use of learning models assisted by e-learning media had a very positive impact on improving students' critical thinking skills. This can be seen from the acquisition of $\mathrm{N}$ Gain for each student's critical thinking indicator in the medium category as many as two indicators, namely indicators providing further explanation and indicators of managing strategies, while the other three indicators get high categories, namely indicators providing simple explanations, indicators of building basic skills, and indicators set strategy or tactics.
\end{abstract}

\section{INTRODUCTION}

The world of education is one side of life that must follow the development of information technology. The sophistication of information technology can be used by educators as an approach to learning. So that the learning that occurs will not cause boredom for students. Saturation of learning does not only occur for students in elementary or high school classes. For students who are adult humans as well as students can also feel bored when learning in the classroom does not go well. Boredom arises due to the effectiveness of teaching or learning that focuses more on the teacher or lecturer, so that generally students are only prepared to take exams, not to understand the concepts that are being studied. Such 
Impact of E-Learning Media on Students' Critical Thinking Skills at Physics Education Study Program ... Marnita, Rahma, Fatimah

learning is more about memorizing concepts [1] [2]. The continuity of such learning patterns will contribute to inhibiting the thinking power of students, which in essence students can think at a high level so that they will try to develop their scientific understanding to solve problems in their learning through various learning processes that begin with hypotheses and then research or investigations. so that they will acquire new knowledge independently [3] [4]. For physics education program students, they already understand that physics lessons are not abstract subjects such as the concepts of thermodynamics, electricity, magnetic induction, and others [5]. This requires an educator to design all facilities for students to understand physics concepts well. One of the learning designs that keep up with the times is learning using an LMS (Learning Management System), which is designed with various features including registration features, virtual classes, social networks, communication, special channels for students to comment or ask questions or collect answers, and also features paper assignment reports and online tests.

In the millennial and modern era, learning with the e-learning system provides a lot of conveniences for students to independently assess their learners anywhere and anytime without time limits [6] [7] [8] [9]. E-learning learning applications will be active if supported by the availability of adequate devices, especially such as Android and a good internet connection [10]. Students can also get the depth of the desired sun through the Moodle e-learning LMS (Learning Management System) [11]. The various advantages possessed by e-learning learning have been applied by the author in a study.

Teaching in the Physics education program FKIP Umuslim currently tends to go through the teacher centre model. This activity is more directed at the lecture method so that students tend to be passive and only receive information from lecturers. If the learning process carried out like this is carried out continuously, then thinking skills will not be developed. Students have difficulty in making decisions logically related to physical concepts. Therefore, the learning and evaluation process needs to be developed through a form of media that can involve students' critical thinking skills. So the authors set the formulation of the problem in this research, namely "Does e-learning have an impact on improving students' critical thinking skills in Physics education study program FKIP Umuslim". The purpose of this study was to determine the impact of e-learning on the improvement of students' critical thinking skills. This is in line with FKIP Umuslim which is one of the LPTKs tasked with producing future teacher candidates for the nation. Therefore, FKIP Almuslim University is committed to providing an education based on student activeness and being able to explore students' higher-order thinking skills. This has been done by a team of lecturers from all study programs at FKIP. One of them is the physics education study program, which changes teaching patterns by promoting Student Center Learning. Various learning activities that are student centre learning, including a learning system with learning media as a learning model, are expected to have a major impact on learning outcomes and student learning enthusiasm. One of the intended learning outcomes is critical thinking skills. One of the higherorder thinking skills is students' critical thinking skills which are sometimes unable to be explored due to the learning process which is only in the basic pattern [11]. There are many solutions that a teacher can do to explore students' critical thinking skills. Among them is the activation of the use of E-Learning media as a teaching model. The use of E-learning media has been running and FKIP ALmuslim University for all study programs, but so far the impact of student-centred learning seems that the Elearning model has never been studied. E-learning is a form of information technology development in the world of education that is currently bumming. E-learning media at FKIP Almuslim University have been introduced since 2016 .

This learning model assisted by E-learning media is a form of learning that is exciting for lecturers and students. This is because this model will require students to take advantage of technological sophistication in the understanding of course material. Students must be proactive themselves if they don't want to miss the material. Activeness and involvement of students in a comprehensive manner in learning can be one of the main components of increasing student learning outcomes in the form of critical thinking skills [12]. Presentation of the material, discussions between students and students, discussions between lecturers and students as well as various learning slides and videos will be obtained by students in the various features in E-learning that have been prepared by each lecturer who teaches 
the Learning model assisted by E-learning media will make it easier for students to learn, because Elearning provides flexibility in choosing the time and place for students to access course material. Elearning media assisted learning model will also present students' independent learning ability and learning will tend to be Student Center Learning. In several writings, it is said that the learning model assisted by E-learning media is more focused on independent learning and in it has been accompanied by tools that can give teachers the flexibility to regulate the e-Learning learning process so that it can minimize misuse that may occur [13] [14]. Furthermore, Hariyanto, et al [10] and Wijaya \& Ramalis [13] stated that "E-learning can be accessed by only using the minimum is android because this learning is online. In the on-line presentation, various work instructions, videos, and teaching materials can be accessed". Furthermore Wijaya \& Ramalis [13] mentions E-Learning as online learning whose performance is greatly supported by technology services such as audio, telephone, satellite transmission, and videotape.

The ease of using E-learning media as a learning model can be used by lecturers at any time. Students have the freedom to explore through the virtual world, namely the E-learning media. This is very helpful, especially for students who tend to be nervous and unable to bring out their abilities when dealing directly with lecturers. Thus, current technology must be viewed as a tool that can facilitate the achievement of learning competencies [14].

Various facilities and technological sophistication in the field of learning will be very useful to improve student learning outcomes. One of the student learning outcomes is the ability to think critically. In principle, the ability to think critically is a high-level ability that a person has at a higher education level. Critical thinking skills that can be explored in a student are giving simple explanations, giving in-depth explanations, making decisions, making conclusions and taking strategic steps [15]. In detail, these five aspects are Elementary Clarification, In-Depth Clarification, Judgment, Inference, and Strategies [15] Furthermore, the ability to think critically as an ability that will be able to train students in several aspects is observing, focusing, analyzing, assuming, hypothesizing, reviewing, and reflecting [11] [16] [17]. From some of these opinions, it can be concluded that critical thinking skills are high-level abilities of a student, even though these thinking skills are not owned by all students, critical thinking skills can be trained and raised through various learning processes [2] [18].

Furthermore, Munawar, et al [19] and Akhdinirwanto, et al [20] stated that "the ability to think critically is a thought process that uses the ability to analyze arguments and give opinions based on logical reasoning. Critical thinking indicators consist of providing simple explanations, building basic skills, making references, providing further explanations, and setting strategies and tactics [11]. The teaching media can be in the form of a combination of media with technological sophistication such as learning media with E-learning. E-learning can simultaneously act as a learning model that can arouse students 'enthusiasm for learning so that the learning process that is Student Center Learning can run and has the potential to improve students' critical thinking skills. Furthermore, Thompson stated that "to awaken students' critical thinking skills, they need a set of appropriate learning models and pay attention to the holistic approach that is used" [21]. Various opinions related to critical thinking skills show that critical thinking skills can be raised from each student with a variety of methods or specific learning models, and this ability is very important to develop at all levels [22] of course, following Ennis states that "Critical thinking is reflective and reasonable thinking that is focused on deciding what to believe or do" [23].

\section{METHOD}

The subjects of this study were the third-semester students of the physics education study program, the Faculty of Teacher Training and Education in the odd semester of 2019/2020. This study is focused on improving students' critical thinking skills and observing the impact of learning using E-learning media as a learning model. The research method used is pre-experimental. Pre-experimental is research that is carried out in one group only. The selected group is called the experimental group which is tested with an initial test and a final test. The initial test is carried out before the treatment is carried out and the 
Impact of E-Learning Media on Students' Critical Thinking Skills at Physics Education Study Program ... Marnita, Rahma, Fatimah

final test is carried out after the treatment is carried out. The test design is to use the one-group pretestposttest design [24] namely:

Table 1. Research Design

\begin{tabular}{ccc}
\hline Pretest & Treatment & Posttest \\
\hline $\mathrm{O}_{1}$ & $\mathrm{X}$ & $\mathrm{O}_{2}$ \\
\hline
\end{tabular}

Information:

$\mathrm{O}_{1}$ : Pretest to see students' critical thinking skills before learning using the E-learning model.

$\mathrm{X}$ : Treatment, namely the E-learning model.

$\mathrm{O}_{2}$ : Posttest to see students' critical thinking skills after learning using the E-learning model.

Quantitative data were collected using the instrument critical thinking skills test items. Furthermore, qualitative data was collected using observation and questionnaires. Quantitative data in the form of an increase in students' critical thinking skills were analyzed based on the results of the pretest and posttest that had been carried out on the student sample. The difference between the mean pretest and posttest scores, where the data distribution was normally distributed, was tested with a parametric statistical test, namely the one-tailed t-test. The category of improving learning outcomes in the form of critical thinking skills is measured using the gain index [25] [26], which states the following success criteria:

Table 2. Criteria for Gain Index

\begin{tabular}{cc}
\hline Category & Range \\
\hline $0,70<\mathrm{g} \leq 1,00$ & High \\
\hline $0,30<\mathrm{g} \leq 0,70$ & Medium \\
\hline $\mathrm{g} \leq 0,30$ & Low \\
\hline
\end{tabular}

\section{RESULTS AND DISCUSSIONS}

\section{Description of Research Data}

This study is an observation of the critical thinking skills of students in physics education study programs and the impact of the application of a learning model with the help of E-learning media as a learning solution that is student centre learning. To get accurate results, researchers have carried out all stages of research, namely data collection, data processing in the form of normality test, homogeneity test, gain index and t-test statistical testing. The items on the critical thinking skills test were given to students in stages, namely pre-test and post-test. The results of the analysis on the initial and final abilities of students' critical thinking skills that have been taught with the E-learning media assisted learning model to indicate that there is a significant difference between the pre-test and post-test tests, which are as follows.

Table 3. Description of the Pre-test and Post-test values

\begin{tabular}{ccccc}
\hline Step & $\begin{array}{c}\text { Minimum } \\
\text { Value }\end{array}$ & $\begin{array}{c}\text { Maximum } \\
\text { Value }\end{array}$ & $\begin{array}{c}\text { Score } \\
\text { difference }\end{array}$ & Average \\
\hline Pre-test & 25 & 55 & 30 & 34.75 \\
\hline Post-test & 60 & 95 & 35 & 72.75 \\
\hline
\end{tabular}

The table shows the differences in student learning outcomes in the form of critical thinking skills at the pre-test and post-test stages. The difference in the acquisition of these average scores shows that the learning process assisted by E-learning media has a significant influence on students. Furthermore, the data analysis of the results of this study is followed by an analysis of the gain index obtained. Analysis of the gain index is carried out after the data is declared to be normally distributed and homogeneous. From the test results, it was found that the data were normally distributed. This can be seen from the data in the pre-test stage $\chi \mathrm{h}$ is 10.8 while $\chi \mathrm{t}$ is 11.07 , this figure shows that the data is normally 
distributed. Furthermore, at the post-test stage, the $\chi \mathrm{h}$ is 9.1 while $\chi \mathrm{t}$ is 11.070 , this figure shows that the post-test data is also normally distributed. Next, the homogeneity test has been carried out. The homogeneity test of the students' mastery of physics concepts can be calculated using the two-variant homogeneity test formula. The test was carried out with a significant level of $\alpha=0.05(5 \%)$ with degrees of freedom $(\mathrm{DK})=\mathrm{n}-1$. The test results show that F-count is 1.35 and F-table is 2.43 , so it can be concluded that the data variant is homogeneous.

Data analysis on the impact of the application of learning models assisted by e-learning media is seen based on the overall acquisition of the N-Gain value and per indicator of critical thinking skills. As for the overall N-Gain test results, it can be seen that there is a difference between the pre-test and post-test values. In general, the N-Gain test aims to see the difference between the initial and final test scores to avoid bias in the results of the research obtained. The N-Gain test for students of the physics education study program in the IPBA course taught by the e-learning media assisted learning model shows an increase in students' critical thinking skills, namely the average result obtained from 34.75 to 72.75 , the average value of $\mathrm{N}$-Gain reached 0.59 in the medium category. The following is a presentation of the data for the students' low, medium and high ranks.

Table 4. Analysis of N-gain Value

\begin{tabular}{cccccc}
\hline No & $\begin{array}{c}\text { Pre-test } \\
\text { score }\end{array}$ & $\begin{array}{c}\text { Post-test } \\
\text { score }\end{array}$ & Gain & N-gain & Category \\
\hline 1 & 5 & 12 & 7 & 0.46 & Medium \\
\hline 2 & 7 & 15 & 8 & 0.61 & Medium \\
\hline 3 & 11 & 19 & 8 & 0.88 & High \\
\hline
\end{tabular}

The overall results of the calculation of the N-Gain value for this research data show very good results. For the perfection of the results of this study, the following will present the results of the analysis of the $\mathrm{N}$-Gain value data for each indicator of critical thinking skills. The student critical thinking indicator consists of five indicators, namely giving simple explanations, building basic skills, concluding, providing further explanations, and arranging strategies or tactics. Next is the improvement of students' critical thinking skills, namely giving simple explanations, building basic skills, concluding, providing further explanations, and arranging strategies or tactics, it can be seen in Figure 1 below:

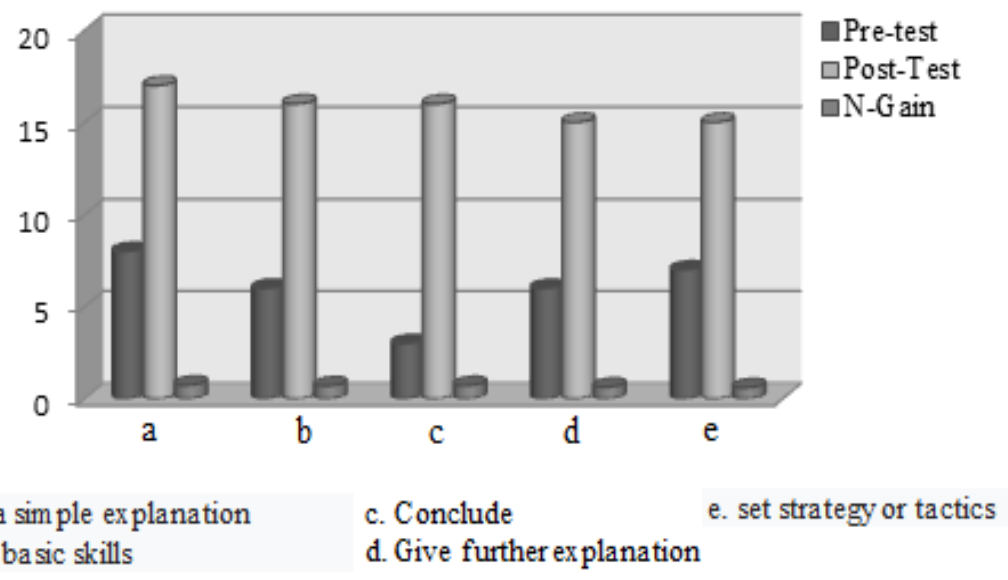

Fig 1. N-Gain Indicator of Critical thinking skills

The data in the table above shows that there is a very significant impact from the application of learning to students assisted by e-learning media. The average critical thinking indicator of students is in the medium and high categories. This is because through e-learning media students have the freedom to explore without having to feel reluctant or awkward towards the tutor lecturers. Learning model assisted by e-learning is one of the learning models which by itself requires students to be active and think. Learning model assisted by e-learning media is also a learning style that can motivate students to be 
active whenever and wherever this is because learning assisted by e-learning media can be accessed by students at any time via a laptop or Android cellphone.

The e-learning media provided by lecturers to students not only contains writings or instructions, but lecturers also fill it with various information related to material, videos that are under the teaching material, and pictures that have a connection with the sub-subject being discussed. This is very much by the teaching pattern for science courses. Image content is part of the concept of scientific thinking because images will be useful for communicating ideas or concepts [27].

\section{T-Test Analysis}

The t-test hypothesis is conducted to determine whether or not the results of the research that have been done The test for $t$ count uses a statistical formula with a significant level of 0.05 with $D K=43$. The testing criteria is to reject Ho if $\mathrm{t}$-count $>\mathrm{t}$-table and accept Ho if $\mathrm{t}$-count $<\mathrm{t}$-table. The following is the t-test result obtained.

Table 5. Hypothesis Analysis of t-test

\begin{tabular}{cccccc}
\hline$\sum$ & Average & Standard Deviation & t-count & t-table & Result \\
\hline 20 & 72.75 & 9.97 & -2.91 & 2.016 & Ho accept \\
\hline
\end{tabular}

Based on the calculation of the t-test hypothesis, it is found that the t-test value is - 2.91 compared to the t-table value with an error rate of $5 \%$ and $\mathrm{DK}=43$, then the t-table value is 2.016 . Thus it can be concluded that the value of $t$ count $<\mathrm{t}$ table is $-2.91<2.016$. So that the testing hypothesis shows that Ho is accepted, namely the application of the E-learning learning model can improve student learning outcomes in the form of critical thinking skills. This also shows that the use of learning models assisted by e-learning media has a very good impact on increasing learning motivation and student learning outcomes. The results of this study are supported by previous research on collaborative e-learning with face-to-face lectures. The research was conducted by Marnita, et al [11] with the title "The Problem Based Instruction Model Based on Blended Learning Against Students 'Critical Thinking Ability in Thermodynamics Subjects", the results of this study indicate that the application of the Blended Learning-based Problem Based Instruction learning model can improve students' critical thinking skills.

This media also makes it easy for lecturers to be able to teach well at all times. Although there are concerns about the misuse of e-learning media by students, this will not happen because the lecturers have the flexibility to manage the e-learning that is being used. This is in line with the statement by Wijaya \& Ramalis [13], namely that because the teacher's presence is not dominant, it is very prone to deviations, but this can be avoided because the teacher has the flexibility to regulate it. This is under previous research by Sukmantara, et al [14], who found that there were significant differences in concept mastery in business material, energy, and power between students who received learning using the physics intranet web media (e-learning) compared to students who received conventional learning. about the acquisition of the final result in this study, the learning model assisted by e-learning media has a very good impact on learning so that the research data shows an increase in student learning outcomes in the form of critical thinking skills. The magnitude of the impact of learning with e-learning media shows that the teaching and learning process must also follow the progress of the melinial, where the use of internet networks and computer applications has good support for the development of student education [28]. Furthermore, the good impact on this learning can be seen from the student's response to this learning process, that $89 \%$ of students stated that they were very happy with learning assisted by e-learning media. Furthermore, 93\% stated that they wish to attend lectures in other subjects using elearning media assisted learning models. The following is a presentation of the results of student responses to learning with the help of e-learning media. 


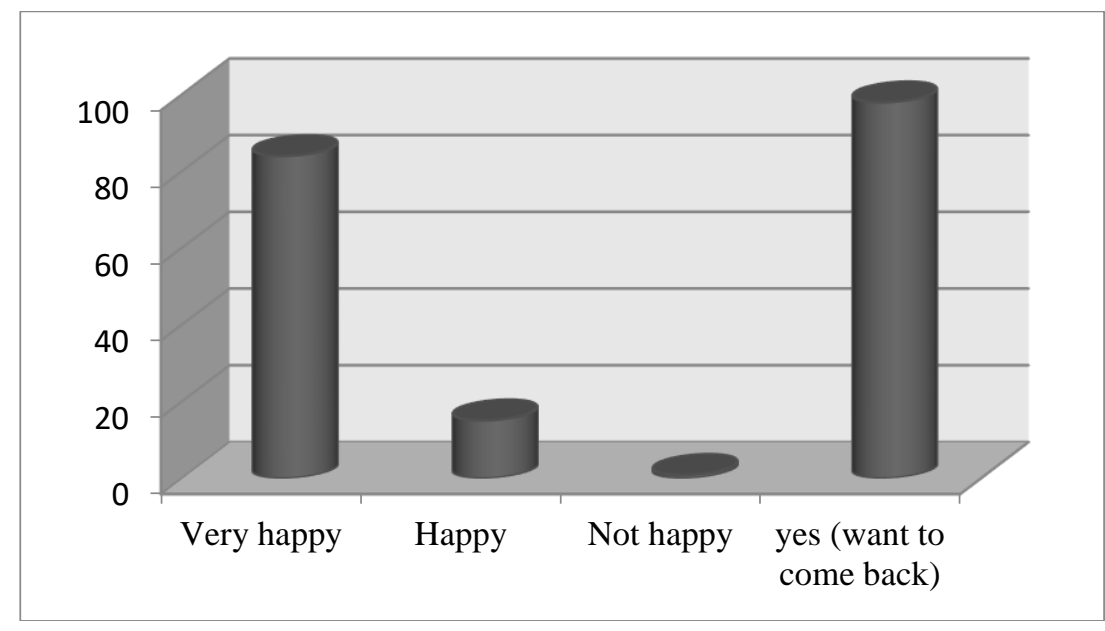

Fig 2. Student Response Graph

Thus the use of learning models assisted by e-learning has a very good impact on increasing the critical thinking skills of students in physics education study programs in IPBA courses. In connection with the results of this study, Turgut, et al [5], Yalcin, et al [29] and Çetin [30] said that the successful application of learning models assisted by e-learning is because the learning process has been taught in the right pattern and accordance with physics material. Furthermore, previous research conducted [2], which found that (1) Project-based science learning with ICT (E-learning) media had excellent response criteria and results, (2) Project-based science learning with ICT (e-learning) media is very good in providing students as early as possible as their provision to master the melinial world.

\section{CONCLUSION AND SUGGESTION}

Learning towards third-semester students in the physics education study program of IPBA courses using the e-learning media assisted learning model has a very positive impact on improving students' critical thinking skills. This can be seen from the acquisition of N-Gain for each student's critical thinking indicator in the medium category as many as two indicators, namely indicators providing further explanation and indicators of managing strategies, while the other three indicators get high categories, namely indicators providing simple explanations, indicators of building basic skills, and indicators set strategy or tactics. Student responses to learning activities assisted by e-learning media $84 \%$ of students stated that they were very happy and $98 \%$ stated that they wanted to attend lectures in other subjects using e-learning media assisted learning models.

\section{REFERENCES}

[1] Vakilifard, A., Bahramlou, K., \& Mousavian, M. (2020). The effect of cooperative learning approach and semantic mapping strategy on the acquisition of L2 Persian vocabulary. Cogent Education, 7(1): 1762287.

[2] Eliana, E. D. S., Senam, S., Wilujeng, I., \& Jumadi, J. (2016). The effectiveness of project-based e-learning to improve ict literacy. Jurnal Pendidikan IPA Indonesia, 5(1): 51-55.

[3] Safarati, N., \& Rahma, R. (2020). Analysis of Students' Understanding of Concepts on Momentum and Impulse Material Using Research-Based Learning (RBL) Models. Indonesian Review of Physics, 3(1): 19-22.

[4] Khoiriah, K., Jalmo, T., \& Abdurrahman, A. (2016). The Effect of Multimedia-based Teaching Materials in Science Toward Students' Cognitive Improvement. Jurnal Pendidikan IPA Indonesia, 5(1): 75-82.

[5] Turgut, U., Colak, A., \& Salar, R. (2016). The Effect of 7E Model on Conceptual Success of 
Impact of E-Learning Media on Students' Critical Thinking Skills at Physics Education Study Program ... Marnita, Rahma, Fatimah

Students in the Unit of Electromagnetism. European Journal of Physics Education, 7(3): 1-37.

[6] Safarati, N., \& Rahma, R. (2019). Penerapan model advance organizer menggunakan Macromedia Flash untuk meningkatkan pemahanan konsep Siswa SMA Negeri 3 Bireuen. Jurnal Riset dan Kajian Pendidikan Fisika, 6(2): 76-81.

[7] Maoto, S. (2014). Creating a Child Friendly Psychosocial Learning Environment in Mathematics: A Case of Problem Solving in Grade 6. Mediterranean Journal of Social Sciences, 5(23): 1048.

[8] Fahyuni, E. F., Wasis, W., Bandono, A., \& Arifin, M. B. U. B. (2020). Integrating Islamic Values and Science for Millennial Students' Learning on Using Seamless Mobile Media. Jurnal Pendidikan IPA Indonesia, 9(2): 231-240.

[9] Elbarbary, R. S. (2015). Identifying Core Mobile Learning Faculty Competencies Based Integrated Approach: A Delphi Study. Journal of Education and Learning, 4(2): 81-95.

[10] Hariyanto, D., Triyono, M. B., \& Köhler, T. (2020). Usability evaluation of personalized adaptive e-learning system using USE questionnaire. Knowledge Management \& E-Learning: An International Journal, 12(1): 85-105.

[11] Marnita, M., Taufiq, M., Iskandar, I., \& Rahmi, R. (2020). The Effect of Blended Learning Problem-Based Instruction Model on Students' Critical Thinking Ability in Thermodynamic Course. Jurnal Pendidikan IPA Indonesia, 9(3): 430-438.

[12] Sinatra, G. M., Heddy, B. C., \& Lombardi, D. (2015). The Challenges of Defining and Measuring Student Engagement in Science. Educational Psychologist, 50(1): 1-13.

[13] Wijaya, A. F. C., \& Ramalis, T. R. (2012). Collaborative Ranking Tasks (CRT) berbantuan Elearning untuk meningkatan keterampilan Generik sains mahasiswa calon guru Fisika. Jurnal Pendidikan Fisika Indonesia, 8(2).

[14] Sukmantara, I. K. Y., Doyan, A., \& Gunawan, G. (2013). Pengembangan Web Intranet Fisika Untuk Meningkatkan Penguasaan Konsep Dan Kemampuan Pemecahan Masalah Siswa SMKN 2 Praya Tengah. Jurnal Pijar Mipa, 8(2).

[15] Rusilowati, A., \& Khanafiyah, S. (2012). Implementasi Model Eksperimen Gelombang OpenInquiry untuk Mengembangkan Keterampilan Berpikir Kritis Mahasiswa Fisika. Jurnal Pendidikan Fisika Indonesia, 8(1).

[16] Setyorini, U., Sukiswo, S. E., \& Subali, B. (2011). Penerapan model problem based learning untuk meningkatkan kemampuan berpikir kritis siswa SMP. Jurnal pendidikan fisika indonesia, 7(1).

[17] Mohseni, F., Seifoori, Z., \& Ahangari, S. (2020). The impact of metacognitive strategy training and critical thinking awareness-raising on reading comprehension. Cogent Education, 7(1): 1720946.

[18] Hidayanti, D., As'ari, A. R., \& Daniel C, T. (2016). Analisis kemampuan berpikir kritis siswa SMP kelas IX pada materi kesebangunan. In Konferensi Nasional Penelitian Matematika dan Pembelajarannya (KNPMP I).

[19] Munawar, M., Roshayanti, F., \& Sugiyanti, S. (2019). Implementation of STEAM (Science Technology Engineering Art Mathematics)-based early childhood education learning in Semarang City. CERIA (Cerdas Energik Responsif Inovatif Adaptif), 2(5): 276-285.

[20] Akhdinirwanto, R. W., Agustini, R., \& Jatmiko, B. (2020). Problem-Based Learning with Argumentation as a Hypothetical Model to Increase the Critical Thinking Skills for Junior High School Students. Jurnal Pendidikan IPA Indonesia, 9(3): 340-350.

[21] Thompson, C. (2011). Critical thinking across the curriculum: Process over output. International Journal of Humanities and social science, 1(9): 1-7.

[22] Wartono, W., Hudha, M. N., \& Batlolona, J. R. (2017). How Are The Physics Critical Thinking Skills Of The Students Taught By Using Inquiry-Discovery Through Empirical And Theorethical Overview?. Eurasia Journal of Mathematics, Science and Technology Education, 14(2): 691-697.

[23] Ennis, R. H. (2011). The nature of critical thinking: An outline of critical thinking dispositions and abilities. University of Illinois, 2(4).

[24] Sugiyono, S. (2015). Metode Penelitian Pendidikan. Bandung: Alfabeta.

[25] Bao, L. (2006). Theoretical comparisons of average normalized gain calculations. American Journal of Physics, 74(10): 917-922.

[26] Hake, R. R. (1998). Interactive-engagement versus traditional methods: A six-thousand-student survey of mechanics test data for introductory physics courses. American journal of Physics, 66(1): 64-74. 
[27] Ainsworth, B. E., Haskell, W. L., Herrmann, S. D., Meckes, N., Bassett Jr, D. R., Tudor-Locke, C., ... \& Leon, A. S. (2011). 2011 Compendium of Physical Activities: a second update of codes and MET values. Medicine \& science in sports \& exercise, 43(8): 1575-1581.

[28] Soparat, S., Arnold, S. R., \& Klaysom, S. (2015). The Development of Thai Learners' Key Competencies by Project-Based Learning Using ICT. International Journal of Research in Education and Science, 1(1): 11-22.

[29] Yalcin, S. A., Turgut, U., \& Büyükkasap, E. (2009). The effect of project based learning on science undergraduates' learning of electricity, attitude towards physics and scientific process skills. International Online Journal of Educational Sciences, 1(1): 81-105.

[30] Çetin, A. (2016). An Analysis of Metaphors Used By High School Students to Describe Physics, Physics Lesson and Physics Teacher. European Journal of Physics Education, 7(2): 1-20. 